Links Between Tourists, Heritage, and Reasons for Visiting Heritage Sites

\author{
Y. Poria \\ Ben Gurion University of the Negev, Israel. \\ R. Butler \\ D. Airey \\ University of Surrey, UK.
}

Dr. Yaniv Poria*

School of Management,

Department of Hotel and Tourism Management

Ben Gurion University of the Negev

Beer Sheva, Israel

Tel + 0097286472193

Fax + 0097286472920

Email yporia@bgumail.bgu.ac.il;

Professor Richard Butler

School of Management Studies,

University of Surrey,

Guildford GU2 7XH, England

Tel + 0044 / 01483 / 689662

Fax + 0044/01483 / 686301

Email R.Butler@Surrey.ac.uk

Professor David Airey

School of Management Studies,

University of Surrey,

Guildford GU2 7XH, England

Tel. + 0044 / 01483 / 689656

Fax + 0044 / 01483 / 686306

Email D.Airey@Surrey.ac.uk

*For correspondence please contact the first author 


\section{Links Between Tourists, Heritage, and Reasons for Visiting Heritage Sites}

\section{ABSTRACT}

This paper aims to clarify heritage tourism by identifying and segmenting reasons for visiting heritage sites. In doing so it highlights the point that the links between a site's attributes and the tourists themselves are essential to understanding tourists' motivations to visit heritage places. The sample was composed of English speaking international tourists leaving Israel through Ben-Gurion airport, who were sampled quasi-randomly. The research was implemented by the use of structured questionnaires using face-to-face interviews. Responses were grouped using an interpretability approach to exploratory factor analysis, and the results indicate that the reasons for visiting can be classified into three. These groups have been labeled 'heritage experience', 'learning experience' and 'recreational experience', and are linked to the tourists' perception of the site in relation to their own heritage and their willingness to be exposed to an emotional experience. The results lead to a better understanding of reasons for visiting heritage places, and provide further insight into heritage tourism in general. The findings are also relevant to the operational management of spaces presenting history-related artifacts as well as to the marketing of these sites.

Key words: heritage, heritage space, motivation. 


\section{INTRODUCTION: THE IMPORTANCE OF UNDERSTANDING TOURISTS'} MOTIVATION

The general interest in the reasons why human beings are involved in certain activities has not passed tourism research by (Parrinello, 1993). Discovering why tourists do certain thing is relevant for (at least) two interrelated reasons: the management of tourism; academic investigation (Haukeland, 1992; Yuan \& McDonald, 1990). A number of studies have established relationships between various aspects of behavior relevant to tourism management as well as its theoretical understanding, related to motivation for tourist's activities. Examples of such behavior are the choice of destination and mode of travel (Pearce \& Catabiano, 1983), expectations (Rekom, 1994) and information sources used (Kim et al., 1996). Other research, emphasizing marketing implications, points out the relationship between an individual's motivation and their socio- demographic characteristics. Such information is helpful for various aspects of marketing such as advertising (Decrop, 1999; Hanqin, 1999).

Understanding motivations is also seen as an important aspect of the academic investigation of tourism. From the early days of tourism research, scholars have looked at the reasons for people being involved in tourist activities (Todd, 1999). Cohen (1974), for example, related reasons for traveling and the purpose of the trip, while trying to answer the question 'who is a tourist?'. The relative importance of the concept of motivation for tourism research and management can also be illustrated by the fact that researchers, when attempting to provide a working definition for 'tourist' or 'tourism', commonly relate to the motives for the travel (Leiper, 1979). 
Motivations have also been used to identify subgroups of tourism, and to distinguish between different groups of tourists. For example, Herold et al. (2001) tried to conceptualize romance and sex tourism with reference to motivating factors while Clift and Forrest (1999) investigated the motivations of gay men with respect to tourist activities. Lang and O'Leary (1997) developed a typology of the nature of travelers based on motivation, and Wight (1996) refers to motivation in her attempt to distinguish eco-tourists from other types. The need to 'know' tourists and their motivations has also been emphasized with respect to managing attractions presenting heritage. In this context, aspects such as interpretation (Moscardo, 1996), visitor satisfaction (Laws, 1998), marketing (Nuryanti, 1996) and visitation patterns (Prideaux \& Kininniont, 1999) have been investigated.

This study aims further to investigate the reasons why people visit a site where historic artifacts are located. It is hoped that such an investigation will contribute to the theoretical understanding of heritage tourism by highlighting whether in order to underlined it as a social phenomenon, there is a need to emphasize the link between the tourists and the space visited. It will also investigate whether heritage tourism is behavior motivated by the search for education and knowledge or whether there is a search for emotional experience that has not yet been identified. Such new understanding of tourists' motivation to visit heritage places will have implications for the practical management of such places as well. Identifying that different tourists visit heritage site for different reasons may lead to the provision of different services for visitors. It may also contribute to more direct marketing, where groups of consumers are approached based on their own reasons for visiting the site. 
The paper starts with a literature review in which the study of motivation in the context of tourism is briefly discussed. The link between the study of motivation and heritage tourism is then presented, and the research objective clarified. Following this, the methodological framework is set out. Finally, the findings are given, and the conclusion and the discussion are presented.

THEORETICAL FRAMEWORK

Motivation in tourism research

Although it is common to refer to 'tourist motivation' (Ryan \& Kinder, 2000; Wight, 1996), understanding the concept of 'motivation' as explored in the literature has come under criticism (Ryan \& Glendon, 1998; Todd, 1999). Pizam et al. (1979), for example, suggest that there is some confusion between motivation and objective. The study of motivation is regarded by some to be the 'thorn in the side' of tourism research (McCabe, 2000:211). Currently the investigation as to "why do tourists travel?' is even more complex as it is difficult to distinguish between notions of recreation, leisure and work (Poria et al., 2003a).

The interdisciplinary nature of tourism gives the researcher the freedom to choose different theoretical backgrounds with which to clarify reasons for travel (Goeldner et al., 2000). There have already been a few attempts to establish a theory as to why people travel. It is argued here that, although these attempts are important and useful, what they present are frameworks and classifications of reasons rather 
than an actual theory. Dann (1977) suggested focusing on the existence of 'anomie' or 'ego-enhancement' as a 'push factor' for a better understanding of tourism, which he saw as 'conducive to the creation of a fantasy world' (Dann, 1977:184). Crompton (1979) classified motivation (in the context of pleasure vacations) according to push and pull factors. Push factors are those that predispose the person to travel, while pull factors are those that attract the potential traveler to a specific destination. This same classification has been used by several others (e.g. Yuan \& McDonald, 1990).

Iso-Ahola (1982) looked at motivation in terms of escape-seeking (again mainly in the context of pleasure tourism). Pearce (1996) has also provided a theoretical framework for the understanding of motivation, suggesting a five-fold hierarchical system, distinguishing between intrinsic and extrinsic motivations. Gnoth (1997:283) relied on 'the behaviorist notion of drive reduction and the cognitive construction of attitudes and values' to develop a theoretical background by emphasizing the holidaymaker's perspective.

Although there is now a body of research centered on tourists' motivation, Dann's suggestion from 1981 may still be relevant. Basically, he questioned whether researchers were investigating the same concept when exploring tourism motivation. Although 15 years have passed since Jafari originally argued that 'there is already a wide range of literature dealing with such motivational propositions, but no common understanding has emerged' (1987:152), the point is still valid. This reflects a notion that can be found even in disciplines such as psychology on which tourism researchers often rely for their theoretical background (Iso-Ahola, 1989). 
Heritage tourism and motivation research

Before exploring reasons for visiting heritage spaces, two interlinked critical issues need to be raised, namely: the difference between tourism in historic places and heritage tourism, and the fact that the study of motivation is commonly centered on notions of leisure, recreation and pleasure.

Heritage tourism is commonly regarded as activity by tourists in a space where historic artifacts are presented (Garrod \& Fyall, 2001). By contrast it is argued in this paper that heritage tourism should be understood based on the relationship between the individual and the heritage presented and, more specifically, based on the tourists' perception of the site as part of their own heritage (Poria, 200la, 2001b; Poria et al., 200la, 200lb, 2003a, 2003b, 2003c). This argument lies at the heart of this research, as perceptions of a site rather than their objective classification may be highly relevant for better understanding reasons for visiting places where historic artifacts are presented.

The second issue raised here by the authors is that studies around the concept of tourist motivation, as well as studies that apply the various theoretical frameworks, are concerned mainly with travel classified as leisure or pleasure related. For example, Haukeland (1992) studied holiday travel, while Aroch (1985), who looked at motivation in relation to socio-demographic characteristics, considered only leisure and recreational travel. Likewise Gnoth (1997), in a theoretical paper about the link between expectation and motivation, decided to emphasize the perspective of holidaymakers. In his classification of push and pull factors (which can be useful for 
our understanding of heritage tourism), Dann (1977:184) relied on the concept of 'fantasy world', as noted earlier. Such understanding and theoretical framework may not apply to reasons for visiting heritage spaces, as those places may not be perceived by visitors as solely 'recreational' or 'pleasure' sites.

There is already research concerning the reasons driving people to visit places where historic artifacts are presented. However, such research often approaches 'heritage tourism' as part of 'cultural tourism' and relies on the leisure and recreation literature. Such research which perceives heritage tourism to be based on the presence of tourists in historic places or places where cultural artifacts are presented, it is argued, does not clarify the nature of the phenomenon (Poria, et al, 2003a, 2003b, 2003c). It is argued that to understand the presence of people in places where, for example, religious artifacts are presented, there is a need to explore elements which are different from those used in the tourism literature. One example is work presented by Davies and Prentice (1995), who tried to provide a theoretical background for understanding why people do not visit museums. They regarded a visit to a museum as a leisure activity, seeing museums as 'heritage attractions'. Another example is that given by Kerstetter et al. (2001), who suggested the segmentation of tourists visiting heritage sites by their interest in history per se.

Prentice et al., clustered visitors to an industrial heritage attraction based on literature under the title 'recreational' (1998:3). This could be appropriate for an industrial heritage park which, apart from being classified as 'heritage', may have nothing to offer visitors which was linked to their heritage. This may explain why, in their classification of those visiting the site, the term heritage is not mentioned. 
Verbeke and Rekon (1996), in their research about the role of museums, identified motivations such as 'to escape from daily routine' and 'to be in the open air', but such motivations have nothing to do with the heritage that lies at the heart of the site. Another example of this ambiguous mix is given by Zeppel and Hall $(1991,1992)$ who decided to combine 'arts and heritage tourism' and to consider them 'as a subset of cultural tourism' (1992:47). This combination may lead to 'cultural motivations' (p.49) or 'learning' (p.53) as a motivation in relation to heritage tourism. Another example, which highlights this issue, is that reported by Zhou et al., (1998) who proposed that one of the main reasons for the Chinese to visit heritage sites is their fame and popularity with others.

Prentice (1993a), in research dealing with heritage consumers in the context of the leisure market, suggested six motivations: pleasure of viewing, education, information, relaxation, entertainment and exercise. It is argued here that these may be applicable to any form of cultural tourism and are not necessarily linked to the heritage presented, which is arguably central to a heritage site. Moscardo (1996), while clarifying the role of interpretation in the context of the management of heritage sites, emphasized two main motivations: educational and entertainment / social. However, it was again felt that the heritage site was perceived mainly as 'another museum' or 'cultural attraction' rather than 'someone's heritage'. The above theoretical background could be helpful to our understanding of a visit, for example, to an art gallery, which some would classify as a heritage attraction (Prentice, 1993b). However, it is doubtful if it would be useful for understanding visitation patterns of Jews to Nazi-related spaces or of New Yorkers to the memorial site that will be built for those who were killed in the attack on the Twin Towers in New York. The 
interpretation of the reason for travel based on only such concepts as leisure and recreation may not be relevant for tourists visiting a site they perceive to be part of their own heritage.

The research problem and its purpose

To summarize, it seems that the two most common reasons to visit a heritage site reported in the literature are education (i.e. the tourists' willingness to learn) and entertainment (i.e. the tourists' desire to be entertained). But other reasons, linked to the attributes of the artifacts presented being related to someone's heritage may also play a part. The present research challenges the current approach, not by denying these two most common reasons, but by adding another, namely the desire of tourists to be exposed to their own heritage and thus to be involved in a personal 'heritage experience'.

Research in environmental psychology, which explores the link between the individual and the environment, supports the notion that the meaning attached to a space is closely linked to one's experience (Carling, 1988; Scott \& Canter, 1997). In heritage tourism an alternative view which challenges the traditional way heritage tourism has been understood, has emerged. In this literature it is argued that the tourists' perceptions of a site and their activities relative to it are important for our understanding of their behavior (Poria, 200la, 2001b; Poria et al., 200la, 200lb).

Based on this viewpoint it is argued that viewing heritage tourism as cultural tourism, as suggested by Nuryanti (1996) who approached built heritage sites as 'the 
heart of cultural tourism' (p.249), is too simplistic. The 'cultural tourism' label hints at activity motivated by curiosity and educational reasons, and ignores the core of such sites- the heritage itself that is presented. This issue is highlighted by the question raised by Swarbrooke (1994): 'heritage - education or entertainment?' (p.225). It is argued that this question may conceal what lies at the heart of this phenomenon: the heritage presented. The importance of such heritage may also be reflected in the reasons for visiting. At this stage it should be emphasized that the aim of this research was not to answer the overall question 'why do tourists visit places presenting heritage?' but to explore whether reasons for such visits are grouped in a certain way which reflects the link between the individual and the object presented. It is suggested that an answer to this question could be helpful for the understanding and management of heritage tourism as a social phenomenon.

In this research it was hypothesized that regarding heritage tourism as simply 'tourists visiting heritage places' would be reflected by a diversity in the tourists' reasons for visiting such sites. Based on the results it was interesting to see whether a structure appeared in which differences could be found between: 1) those reasons already mentioned in the literature in relation to heritage attractions and 2) reasons associated with the actual heritage presented. If found, such differences would begin to challenge the questions: are tourists seeking an educational or entertaining experience, or is there something else going on that has yet to be discovered?. If those differences could be linked to the tourists' perception of the site as part of their own heritage it would further support the notion that heritage tourism should be investigated based on the links between the site and the tourists. Such an understanding could provide knowledge useful for improving a variety of aspects of 
the management of attractions presenting heritage, including marketing, interpretation and operations. The results may also make a theoretical contribution by suggesting that the understanding of certain forms of tourist behavior should be based not only on research from leisure and recreation as is commonly the case, but should also consider areas such as religion, where a sense of commitment and obligation are common factors affecting behavior. The research could also suggest that understanding tourists' behavior should not be based only on the attributes of the site or the characteristics of the tourists but also on the link between the two.

\section{METHODOLOGICAL FRAMEWORK}

The sites

To provide a better clarification of the research problem it was decided to investigate two different sites: the Wailing Wall in Jerusalem; Massada in the south of Israel. It was thought that investigating two sites, substantially different in their attributes, would support possible generalization of the findings.

The Wailing Wall is considered to be the most important religious site for Jews, with historic meaning arising from the fact that it is believed to be part of the original Temple. It is also associated with Israel's victory in the Six-Day War, which for Zionists symbolizes the existence of an independent Jewish state. The Wailing Wall also relates to Christianity on religious grounds, as Jesus stood there and prophesized the downfall of the Temple (Schiller, 1992; Eder and O'Sullivan, 1989). 
As a heritage site the Wailing Wall has a number of key characteristics specifically relevant to this research. First, it was recognized that choosing the Wailing Wall would bring into play religious-related motivation associated with the Bible, as well as that associated with the history of the state of Israel. Clearly this is likely to have an effect on the motivations of many of those who visit the site. However, it was also felt that it would not limit the diversity of motivation among the visitors due to its location and it being a 'must see' site for a wide range of visitors. Secondly, apart from viewing the Wailing Wall, there is nothing else to do there except pray or observe those who pray. There are no other attractions such as restaurants, entertainment facilities or breathtaking scenery. This factor is relevant to the research problem, as it will help clarify our understanding of the reasons for visiting the site. Thirdly (in common with several other heritage attractions), entrance is free, and thus a potential barrier (i.e. direct cost) to entering the site is removed. It is suggested that this could result in a variety of visitors who are motivated on different grounds. This notion was supported by an official report of the Israel Ministry of Tourism, which suggested that the Wailing Wall was the most popular tourist attraction in Israel (Israel Ministry of Tourism, 1996, 1997, 1998).

Massada was chosen because its attributes are different from the Wailing Wall. Massada is a historic site per se, and a site that presents history, which some visitors perceive to be part of their own heritage. However, in contrast to the Wailing Wall, Massada, apart from presenting historic artifacts provides visitors with a spectacular view of the desert, the Dead Sea, and Jordan. The site is famous for its role in the Jewish revolt against the Romans (in AD 70), where it was the last pocket of Zealot resistance. The rebels decided not to surrender, but to kill each other so as 
not to be enslaved by the Romans and made to follow their religion (Mehling, 1987). Because of this the site has symbolic meaning and is commonly involved in the political discourse in today's modern Israel. Unlike the Wailing Wall it is not located relatively close to other sites. Massada lies in the south of Israel, around 3 hours driving time from Tel Aviv, which suggests that visitors will not come to the site "by accident'. Also one needs to pay an entrance fee. It is also different from the Wailing Wall where a visit may take less than five minutes, in that at Massada the actual length of visit is commonly three to four hours.

It was felt that these two sites represent two kinds of heritage attractions. The Wailing Wall is a site which has at its core history which may be linked to different people on different grounds. To some the heritage is perceived as highly linked to their identity, while for others it is not. Massada is an example of a site that provides its visitors with more than a heritage experience only (e.g. the view from the site, a visit to the desert area). Moreover, while the history presented may be perceived differently by different tourists, is not highly linked to the tourist's own heritage

Research implementation

The research tool was a structured questionnaire implemented through face to face interviews. It was decided to interview international tourists after they had completed their visit to Israel. The interviews were conducted in the main Israeli airport while the tourists were waiting for their flights as this provided a diversity of tourists essential to answer the research question. The objective of the sampling strategy chosen (a theoretical sample) was not to achieve a representative sample of 
all international tourists visiting the Wailing Wall and Massada, but to include a diversity of tourists. Such a research strategy which aims at finding diversity rather than representing the population could benefit the generalizations of the findings. The fieldwork was planned for a period when there would be maximum diversity of visitors. The population was international tourists leaving Israel through Ben-Gurion airport who were able to speak and understand English, and were above 15 years old (as at this age cognitive abilities are considered to be stable: Apter et al., 1998). The reason for confining the population to international tourists was based on the assumption that there is greater diversity among this population than among the local population (especially in the context of the sites investigated). Interviewing as tourists departed Israel means that the memories about their visit were relatively fresh.

Every Nth' tourist was approached while the tourist were waiting for their flight (the interviewees were asked not to approach participants in the duty-free shops). The value of $\mathrm{N}$ was determined by factors such as the number of interviewers, the number of flights departing in a certain time period, the number of tourists waiting for a flight and the time remaining to flight departure. Before inclusion in the sample, the interviewees were asked to confirm whether or not they were tourists. The participants were first asked if they were tourists to Israel and if they stayed in Israel for more than 24 hours. Then the tourists were asked if they had had a chance to visit different places in Israel. Only those answering in the affirmative were included. The interviews were conducted by five students selected after being interviewed by one of the authors. 
A feasibility study took place in December 1999, and then at the beginning of April 2000 the pilot study was conducted. The actual study took place between April and May 2000 (this was done to avoid religious holidays and a Papal visit which may have had an influence on the diversity of the tourists). Almost 400 (398) interviews were conducted. Around fifteen percent of the respondents asked not to participate in the study, usually mentioning that they were tired or working. The interviews took place at day and night times on weekdays and weekends, usually taking around 20 minutes. A small token incentive was given to the interviewees at the end of the interview.

Establishing the research tool

A quantitative research approach was applied in this study. To address the research problem it was necessary to investigate the relationship between the tourists' perception of a site in relation to their own heritage, and their motivations to visit that site. After short introduction the participant were asked series of question which aim to find out if they are international tourists. Then participants were asked series of questions about the site only if they had visited them. The tourists were also asked several questions about their perception of the site visited in relation to their own heritage. At the end of the interview the tourists were asked several questions about their personal characteristics.

The tourists were asked to comment about their level of agreement or disagreement with statements dealing with possible reasons for their visit. They 
were asked to answer using a 0 to 6 scale (where 0 represents 'I completely disagree' and 6 represents 'I completely agree') and provided with a show-card for illustrating their answers. This was done to minimize social pressure, as participants were often near their friends/family/colleagues during the interview.

The motivation list was developed in such a way as to emphasize the different attributes of the sites as described in different guidebooks, as well as including common reasons for activities mentioned in the literature dealing with visitation patterns to heritage spaces. The reason for referring to tourist guidebooks was based on the rationale that their description reflects a variety of interests and as such provides a diversity of reasons essential for this study. These include: a space to pray, a site which presents historic artifacts, a site that is located close to other tourist attractions, a site in which religious people can be observed while praying, and a site that is related to a person's own heritage. Reasons not directly linked to the heritage presented included: located in an open space, a possible place to have a day out, the visual appearance of the site, the absence of an entrance fee, and, it is a 'must see' site (like being in Paris and 'having to see' the Eiffel Tower).

The analysis

The findings are based on differences among groups. A factor analysis (FA) technique was also used to explore interrelationships among the responses. In this research, principal-component analysis was used, because of its attribute as the 'first step in FA where it reveals a great deal about probable number and nature of factors' 
(Tabachnick and Fidell, 1996:664). Then oblique rotation was carried out because of the assumption that the actual factors are related to each other, while the assumption behind orthogonal rotation is that the factors are not related.

Description of the sample

The entire sample consisted of 398 participants, of whom 304 (77.6\%) and $136(34.2 \%)$ had visited the Wailing Wall and Massada respectively during their present visit. Of those who had visited the Wailing Wall, $57.6 \%$ were male and $42.4 \%$ female. In Massada 58.8\% were male and 41.2\% female (the gender distribution for the entire sample was $61.8 \%$ male and $38.2 \%$ female). This unequal ratio of men to women could be due to business travelers in the sample, who are more likely to be men than women. The mode age group was 20-29 among the visitors to both Massada and the Wailing Wall.

Of those who visited the Wailing wall $24.7 \%$ (75) were Jewish, $64.8 \%$ were Christians (197) and 8.7\% identified themselves as Muslims, Other or No Affiliation. In the context of Massada $19.9 \%$ were Jewish (27), $75 \%$ were Christians (102) and $5.1 \%$ (7) identified themselves as Muslim, Other or No Affiliation

\section{FINDINGS}

Results 
The results section is composed of different subsections based on the research objectives. First, the results of the factor analysis are presented both for Massada and the Wailing Wall. Following this the links between the factors and the tourists' perceptions of the heritage sites in relation to their own heritage are presented.

\section{Tourist motivations to visit heritage site}

It was essential to this study to name and determine the number of factors among the tourists' motivations to visit heritage sites. The number of factors to be retained is often regarded as the most essential task in interpreting results (Hammond, 2000). Different approaches can be used for the extraction of variables. One of the most popular is to extract only as many factors as have Eigen-values greater than or equal to one, identified as the Kaiser low (the Kaiser low approach actually specifies not to include variables that have Eigen-values smaller than one). A second method is by interpretability, when theory or other data suggest a certain solution. The third approach is the use of the Scree plot. The approach chosen in this research was that of interpretability. Based on the theoretical background of this study, it was suggested that there are three groups of reasons: those that are linked to the site being related to the tourist's own heritage (rarely discussed in the literature), those that are linked to the site as it presents historic artifacts, and a third group not linked to the place being a heritage/historic site (already identified in the literature). The meaning of a factor is determined by the items that are associated with it. In order to decide which motivations are included in each factor it was decided to include those that were correlated above the 0.4 level (larger than +0.4 and smaller than -0.4 (Fife-Schaw, 2000; Hammond, 2000). 
In the context of the Wailing Wall, constructing an inter-variable correlation coefficient matrix among the reasons for visiting revealed a relatively large number of Pearson's correlation coefficients between many of the identified reasons. Among these, some relatively highly correlated factors were found. Another aspect worth mentioning at this stage is the fact that some of the Pearson's correlation coefficients were negative. This means that, just as the tourists are motivated to visit the site by certain reasons, they weree made less motivated by other reasons. This kind of relationship suggests that if latent traits are found they may be associated with other traits, both positively and negatively. The actual loading and the factor names are presented in the Table 1.

Table 1 here

Based on the above table, it is suggested that there is a very clear distinction between the nature of the three constructs. The first component embodied reasons linked to the tourists' perception of the site as part of their own heritage. The second group of reasons has nothing to do with the content presented at the site, and is linked to the site as a recreational place. The third group of reasons is related to the attributes of the site as an historic place in general. Another way to distinguish between these three groups is that the first factor is commonly linked to the tourists' emotional involvement 'with the heritage presented' and the third relates to the tourists' willingness to learn. The second group of reasons has nothing to do with the tourists' involvement with the site. This division suggests that the reasons to visit could be divided into those reasons which are linked to the heart - the emotional experience - linked to the brain - the intention to learn -, and not linked with the core of the site - the material subject matter presented. 
It can be seen that some of the reasons load on two components. For example, the reason 'Because you felt you should visit the site' is loaded above 0.4 on the learning component and the emotional component. This means that those who want to have a 'heritage experience' as well as those looking for a 'historic cultural experience', were motivated to visit because they perceive the visit to be important (although this perceived importance may spring from different reasons). Another interesting finding is that the item 'It is a world-famous site that you had to see once in your life' is associated positively with the tourists' motivation to learn, but negatively with the tourists' willingness to be involved in a heritage experience. This means that, as these tourists were more motivated to visit the site because it is worldfamous, they were less motivated to visit in order to be involved in a heritage experience.

Table 2 presents the reasons in the context of Massada. The results presented further support the thought that three factors are at the core of the understanding of tourists' motivation to visit heritage sites.

Table 2 here

As can be seen from table 2 the loading of the items on the factors were very similar to those identified in the context of the Wailing Wall. A difference was found in the case of only one reason - 'because it is a world famous site that you had to see once in your life'. In the case of the Wailing Wall this reason was loaded on two factors, positively on the 'learning factor' and negatively on the 'heritage factor'. In the context of Massada it was highly loaded on the 'learning factor' only. It is suggested that the reason for the difference is that those who perceive the Wailing Wall as part 
of their own heritage do not visit the site because it is a famous tourist attraction and they tend to visit the site more than once. To further clarify this point there is a need to explore the link between the tourists' perceptions and their motivations to visit the sites.

The link between the tourists' perceptions of the heritage presented and the factors $\underline{\text { identified }}$

The tourists were asked a series of five questions to capture their perception of the sites in relation to their own heritage. The participants were presented with statements and a 0 to 6 scale (i.e., 0 means 'absolutely not part of my own heritage' and 6 'absolutely part of my heritage'). The distributions of the answers are presented in Table 3.

Table 3 here

As can be seen from the above table the patterns for the Wailing Wall and for Massada are substantially different. In the case of the Wailing Wall there is a bi-polar distribution (i.e. the site is either part of the tourists' own heritage or not), while in the context of Massada the distribution is positively skewed (i.e. most of the sample perceive the site as not belonging to their own heritage).

To investigate the relationship between the tourists' perception of the site in relation to their own heritage and their motivations for the visit several procedures were conducted. As a starting point a reliability test was carried out on the questions listed in Table 3 (the Cronbach Alpha was above 0.8, indicating relatively high reliability). Then the tourists' perception of the site was identified as the average of 
the answers presented in the above table. The reasons for the visit were then grouped into three as was suggested earlier: Desire to be involved in a heritage experience, desire to learn, and desire to obtain a recreational experience. An average was computed for each group. Pearson Correlations were then computed (Table 4) suggesting that there is a direct link between the tourists' perception of a site and their reasons for visiting (non-parametric tests also conducted revealed the existence of relationships).

The fact that such high levels of correlation were found suggests that there may be a difference between the tourists based on their perception of the sites and their motivation to visit the sites. To determine if such differences exist, the tourists were grouped into three: those that perceived the site to be absolutely part of their own heritage; those who did not consider the site to be part of their own heritage; and those that were in between. The actual groups were identified based on the average of the questions dealing with the tourists' perception of the site as presented in table 3 . Those tourists whose answers ranged from 0 to 1.5 (who perceive the site as not part of their own heritage), those tourists whose answers ranged between 4.5 and 6 (who perceive the site to be part of their own heritage), and those answers who ranged between 1.5 and 4.5. The actual differences are presented in Table 5 based on Oneway Anova analysis.

Table 5 here

The data presented suggest first that the average of each motivation is different for each site which is not surprising as the two sites are substantially different from each other. It is important for this study that the data presented indicate that perceptions of the sites in relation to the heritage are highly linked with some of the 
factors identified before as reasons to visit the sites. Most important for this study were significant differences found among all the groups at both sites relating to their intention to be involved in a heritage experience. At the Wailing Wall a significant difference was found in the motivation to learn between those who did not perceive the site as part of their heritage and other groups. This suggests that those tourists who did not perceive a site as part of their heritage were less motivated to learn about that site, a fact which may be of importance in the context of heritage sites management. In the context of Massada those tourists who perceived the site as part of their own heritage were more motivated to learn about the site. These findings may be important for the management of heritage sites as discussed later.

\section{CONCLUSION AND DISCUSSION}

Summary

This study offers two main contributions for the theoretical investigation of heritage tourism. First, results indicate that the reasons for visiting spaces in which heritage is presented can be placed into three groups under the headings 'heritage experience', 'learning history' and 'recreational experience'.

The first group identified contained those reasons that did not relate to the content of the material presented. This group was made up of reasons such as the desire to have a day out, the cost of entrance, the desire to be entertained, wanting to see a world-famous site, and the desire to relax. 
The second and third groups of reasons have some things in common, but are seen here as being different from each other overall. One group of reasons is based on the link between the subject matter (i.e. heritage presented) and the tourists' perception of this material in relation to their own heritage. This group expressed reasons such as: because it is part of your own heritage, a desire to pray there, desire to be emotionally involved, and a sense of obligation. For present purposes, this group could be put under the heading of 'a desire to be involved in the heritage experience'.

The third group is those with reasons that are linked to the site being a historic one which people are visiting to observe and learn about. Among these reasons are desire to learn, the physical nature of the site and its historic background. The findings also suggest that some of the reasons can be assigned to more than one factor, although their loading with each is different. Another interesting pattern was found in relation to 'Because it is a world - famous site that you had to see once in your life'. This was positively linked to the 'recreational experience' and 'history observation' but negatively correlated to the 'heritage experience'.

The findings further indicate that differences in perceptions of a site are reflected in differences in reasons for visiting a site. This supports the notion that the link between the individual and the site is at the core of the understanding of heritage tourism as a social phenomenon. Differences were found among the tourists in those three factors identified. This emphasizes the point that the heritage exhibited at a site is at the core of a visit for some tourists, those who seek a heritage experience, the heritage tourists. 
Discussion

The findings suggest that site attributes themselves are important to understanding reasons for visiting a site, but that the perception of these attributes is a key issue. This study suggests that the 'past' presented at a site motivated the tourists on different grounds. There is a desire to learn about the history, and to take part in a recreational activity. However, to conclude, in contrast to other research, this study suggests that there is also another factor - the tourists' desire to be exposed to material that is part of their own heritage.

These results support the argument that behavior depends on perception of a site in relation to personal heritage rather than just site attributes (Poria, 200la, 200lb; Poria et al., 2001, 2003a, 2003b). The meaning attached by the tourists lies at the heart of this research. This may suggest that any research aimed at explaining visitation patterns or experiences in certain settings should also consider subjective notions and the significance attached to sites (Poria et al., 2001b).

This research also reveals that some of reasons for visiting heritage sites are in contrast to notions such as recreation and leisure (e.g. 'I felt a sense of obligation to visit the site'). This may show a need to consider more than merely 'leisure motives' (see, for example, Ryan and Glendon, 1997) in motivational studies. It is argued that research that uses 'leisure scales' and sees 'holidaymakers' simply as those involved in leisure and recreation activities, may not be appropriate to some forms of tourism or specific experiences such as heritage tourism. It has been suggested that 
researchers may need to look to other disciplines in order to understand certain forms of tourism that are not only undertaken in 'leisure time' and are not 'recreational' (Poria et al, 2003a, 2003b). One possible example of such an area of research is religious studies, where a sense of obligation is suggested to explain individual behavior.

Implications and future research

As is the case in all research this study has a number of limitations. Prominent among these is the fact that only two sites were studied. It is recognized that a future study would gain by including a greater diversity of sites. Further studies should explore sites with different characteristics to the ones chosen here, and could therefore indicate if the findings of this study could be applicable to other places. Future research also could explore the link between factors identified here and issues such as tourists' personal characteristics or their expectations from a visit, as well as their satisfaction afterwards. Such investigation could, in turn, lead to better management and higher levels of satisfaction among visitors.

This study identified three main reasons for visiting a heritage site. The knowledge that tourists visit heritage places on more than educational and recreational grounds clearly has potential implications for the management and decision makers of such places. The notion that visitors may also show an interest in being 'emotionally involved' and may feel a 'sense of belonging to the site' and visit 'because it is part of their heritage' should also be reflected in the operational management of such sites. 
For example, these concepts could be borne in mind in marketing and in relation to the interpretation provided. There may be a place to reflect these reasons in advertising campaigns. The fact that tourists are motivated to visit for emotional reasons may be reflected in the interpretation provided. There could be more of an effort made not just to educate visitors, but also to provide them with an emotional experience. The findings of this study could also contribute to decision making, such as by government organizations, which are responsible for the management of several heritage sites. For example, as it was established that some tourists visit to feel emotionally involved while others come to be educated, those responsible for the tourism industry could bear this in mind in their location strategies The findings could also assist tour operators to establish appropriate routes for their customers better to reflect their interests. Future research in this area could explore more specifically the link between the interest in interpretation, in relation to motivation to visit, and perceptions of site and may lead to a decision to provide different interpretation to different tourists.

To conclude, it is suggested that the question raised by Swarbrooke (1994): 'Heritage - education or entertainment?' is incomplete and ignores those who specifically visit to experience their own heritage rather than observe that of others. Using Urry's (1990) terminology, it is argued that tourists do not only visit settings where 'their' history is presented just to 'gaze' but also sometimes to engage with what is there. 
Reference list

Apter, A., Hatab, J., Tyano, S., and A. Weizinan. (1998). Child and Adolescent Psychology.Tel-Aviv: Dyonon Publishing.

Aroch, R. (1985). "Socio-economic research into tourist motivation and demand patterns." The Tourist Review, 4:27-29.

Bryman, A., and D. Cramer. (1999). Quantitative Data Analysis. London: Routledge. Carling, T. (1998). "Introduction - conceptualizations of human environments.” Journal of Environmental Psychology, 18: 69-73.

Clift, S., and S. Forrest. (1999). "Gay men and tourism: destinations and holiday Motivations." Tourism Management, 20(5): 615-625.

Cohen, E. (1974). "Who is a tourist? A conceptual clarification.” Sociological Review, 22(4): 527-555.

Crompton, J.L. (1979). “Motivations for pleasure vacation.” Annals of Tourism Research, 6: 408-424.

Dann, G.M.S. (1977). “Anomie, ego-enhancement and tourism.” Annals of Tourism Research, 4(4): 184-194. 
(1981). "Tourist motivation: an appraisal.” Annals of Tourism Research, 8(2): 187-219.

Decrop, A. (1999). "Personal aspects of vacationers decision-making processes: An interpretivist approach.” Journal of Travel and Tourism Marketing, 8(4): 5968.

Davis , A., and R. Prentice. (1995). "Conceptualizing the latent visitor to heritage Attractions." Tourism Management, 16(7): 491-500.

Fife-Schaw, C. (2000). Personal communication. Editor of research methods book and lecturer for research methods in the Psychology Department at the University of Surrey, Eng.

Garrod, B., and A. Fyall. (2001). "Heritage tourism: A question of definition.” Annals of Tourism Research, 28: 682-708.

Goeldner, C.R., Ritchie, J.R.B., and R.W. McIntosh. (2000). Tourism: Principles Practices Philosophies. New York: John Wiley \& Sons.

Gnoth, J. (1997). “Tourism motivation and expectations formation.” Annals of Tourism Research, 21(2): 283-304.

Hammond, S. (2000). Personal communication. Editor of research methods book 
Hanqin, Z.Q., and T. Lam. (1999). "An analysis of mainland Chinese visitors' motivation to visit Hong Kong." Tourism Management, 20: 587-594.

Haukeland, J.V. (1992). "Motives for holiday travel." The Tourist Review, 11: 14-17.

Herold, E., Garcia, R., and T. DeMoya. (2001). "Female tourists and beach boys: romance or sex tourism.” Annals of Tourism Research, 28(4): 978-997.

Iso-Ahola, S.E. (1982). "Towards a social psychology theory of tourism motivation." Annals of Tourism Research, 9: 256-262.

(1989). “Motivation for leisure.” In Understanding Leisure and Recreation: Mapping the Past, Charting the Future, edited by E.J. Jackson and T.L. Burton. Oxford: Venture Publishing, pp. 247-79.

Israel Ministry of Tourism. (1998). Tourist survey. Jerusalem: Israel Ministry of Tourism. (1997). Tourist survey. Jerusalem: Israel Ministry of Tourism. (1996). Tourist survey. Jerusalem: Israel Ministry of Tourism.

Jafari, J. (1987). “Tourism models: The sociocultural aspects.” Tourism Management, 8: 151-159. 
Kerstetter, D.L., Confer, J.J., and A.R. Graefe. (2001). “An exploration of the specialization concept within the context of heritage tourism.” Journal of Travel Research, 39(3): 267-274.

Kim, Y., Weaver, P., and K. McCleary. (1996). "A structural equation model: The relationship between travel motivation and information sources in the senior travel market." Journal of Vacation Marketing, 3(1): 55-66.

Lang, C.T., and J.T. O’Leary. (1997). "Motivation, participation and preference: A multi- segmentation approach of the Australian nature travel market." Journal of Travel and Tourism Marketing, 6(3/4): 159-180.

Laws, E. (1998). “Conceptualizing visitor satisfaction management in heritage settings: An exploratory blueprinting analysis of Leeds Castle, Kent." Tourism Management, 19(6): 545-554.

Leiper. N. (1979). “The framework of tourism: Toward a definition of tourism, tourist, and the tourist industry." Annals of Tourism Research, 6(4): 390-407.

McCabe, S. (2000). "The problem of motivation in understanding the demand for leisure day visits.” In Consumer Psychology of Tourism, Hospitality and Leisure, edited by A.G. Woodside., G.I. Crouch., J.A. Mazanec., M. Oppermann, and M.Y. Sakai. Oxon: CABI Publishing. pp. 211-25. 
Mehling, M. (1987). Jerusalem and the Holy Land, Oxford: Phaidon.

Moscardo, G. (1996). "Mindful visitors: Heritage and tourism.” Annals of Tourism Research, 23(2): 376-397.

Moulin, C.M. (1991). "Cultural heritage and tourism development in Canada." Tourism Recreation Research, 16(1): 50-55.

Nuryanti, W. (1996). "Heritage and postmodern tourism.” Annals of Tourism Research, 23(2), 249-260.

Parrinello, G.L. (1993). Motivation and anticipation in post-industrial tourism. Annals of Tourism Research, 20(2): 233-249.

Pearce., P.L. (1996). "Recent research in tourists' behaviour." Asia Pacific Journal of Tourism Research, 1(1): 7-17.

Pearce, P.L., and M.L. Caltabiano. (1983). "Inferring travel motivation from travelers' experiences." Journal of Travel Research, 17: 16-20.

Pizam, A., Neumann, Y., and A. Reichel, A. (1979). "Tourists satisfaction: Uses and misuses.” Annals of Tourism Research, 6(2): 195-197.

Poria, Y. (2001). "Challenging the present approach to heritage tourism: Is tourism to heritage places heritage tourism?." Tourism Review, 56(1/2): 51-53. 
(2001). “The show must not go on.” Tourism and Hospitality Research, 3(2):

115-119.

Poria, Y., Butler.R., and D. Airey. (2000). "Clarifying heritage tourism: A distinction between heritage tourism and tourism in historic place." Annals of Tourism Research, 28(4): 1047-1049.

(2001). “Tourism sub-groups: Do they exist?.” Tourism Today, 1(1): 14-22.

(2003a). "Revisiting Mieczkowski's conceptualisation of tourism."

Tourism Geographies, 5(1): 26-38.

(2003b). "The core of heritage tourism: Distinguishing heritage tourists from tourists in heritage places." Annals of Tourism Research, 30(1): 238-254.

(2003c). "The meaning of heritage sites for tourists: The case of Massada." Tourism Analysis. (Forthcoming)

Prentice, R. (1993a). "Motivations of the heritage consumer in the leisure market: An application of the Manning-Haas demand hierarchy." Leisure Sciences, 15: 273-290.

-(1993b). "Heritage: A key sector of the "new" tourism." Progress in 
Tourism, Recreation and Hospitality Management, 5: 309-324.

Prentice, R.C., Witt, S.F., and C. Hamer. (1998). "Tourism as experience: The case of heritage parks." Annals of Tourism Research, 25(1): 1-24.

Prideaux, B.R., and L.J. Kininmont, L.J. (1997). “Tourism and Heritage are not strangers: A study of opportunities for rural heritage museums to maximize tourism visitation." Journal of Travel Research, 37: 299-303.

Rekom, J.V. (1994). “Adding psychological value to tourism products.” Journal of Travel and Tourism Marketing, 3(3): 21-36.

Ryan, C., and I. Glendon. (1998). "Application of leisure motivation scale to tourism." Annals of Tourism Research, 25(1): 169-184.

Ryan, C., and R. Kinder. (2000). "Sex, tourism and sex tourism: Fulfilling similar need?." In Tourism Management: Towards the New Millennium, edited by C. Ryan, and S. Page. Amsterdam: Pergamon. pp. 113-32.

Schiller, E. (1992). Guide to Christian Historical Sites and Holy Places in Israel, Jerusalem: Arial.

Scott, M.J., and D.V. Canter, D.V. (1997). "Picture or place? A multiple sorting study of landscape.” Journal of Environmental Psychology, 17: 263-281. 
Swarbrooke, J. (1994). "The future of the past: Heritage tourism into the 2lst century." In Tourism: The State of the Art, edited by A.V. Seaton. Chichester: John Wiley \& Sons. pp. 222-29.

Tabachick, B.G., and L.S. Fidell. (1996). Using Multivariate Statistics, New York: Harper Collins College.

Todd, S. (1999). "Examining tourism motivation methodologies." Annals of Tourism Research, 26(4): 1022-1024.

Urry, J. (1990). The Tourist Gaze: Leisure and Travel in Contemporary Societies, London: Sage Publications.

Verbeke, M.J., and J.V. Rekon. (1996). “Scanning museum visitors: Urban tourism marketing." Annals of Tourism Research, 23(2): 364-375.

Wight, P.A. (1996). "North American ecotourism markets: Motivation, preferences and destinations." Journal of Travel Research, 35(1): 3-10.

Yuan, S., and C. McDonald, C. (1990). "Motivational determinates of international pleasure time." Journal of Travel Research, 29(1): 42-44.

Zeppel, H., and C.M. Hall. (1992). “Arts and heritage tourism.” In Special Interest Tourism, editors C.M.Hall, and B.Eiler. London: Belhaven Press. pp. 47-68. 
Zeppel, H., and C.M. Hall. (1991). "Selling art and history: Cultural heritage and tourism." The Journal of Tourism Studies, 2(1): 29-45.

Zhou, L., King, B., and L. Turner. (1998). "The China outbound market: An evaluation of key constraints and opportunities." Journal of Vacation Marketing, 4(2): 109-119. 
Table 1: Matrix of motivations to visit the Wailing Wall

\begin{tabular}{|c|c|c|c|}
\hline \multirow[b]{2}{*}{ Tourist motivation* } & \multicolumn{3}{|c|}{ Components** } \\
\hline & $\begin{array}{c}\text { Heritage / } \\
\text { Emotional } \\
\text { Experience } \\
4.461\end{array}$ & $\begin{array}{c}\text { Recreational } \\
\text { Experience } \\
2.308\end{array}$ & $\begin{array}{c}\text { Cultural } \\
\text { /Educational } \\
\text { Experience } \\
1.480\end{array}$ \\
\hline $\begin{array}{l}\text { Because you felt a sense of belonging to the } \\
\text { site }\end{array}$ & 0.880 & & \\
\hline Because it is part of your own heritage & 0.832 & & \\
\hline $\begin{array}{l}\text { Because you wanted to feel emotionally } \\
\text { involved }\end{array}$ & 0.822 & & \\
\hline Because you wanted to pray there & 0.758 & & \\
\hline Because you felt obliged to visit the site & 0.660 & & \\
\hline Because it is important to visit the site & 0.538 & & \\
\hline Because you felt you should visit the site & 0.471 & & 0.424 \\
\hline Because of its religious characteristics & 0.435 & & \\
\hline $\begin{array}{l}\text { Because it is a world-famous site that you had } \\
\text { to see once in your life }\end{array}$ & -0.403 & & 0.460 \\
\hline Because you wanted to learn about the site & & & 0.820 \\
\hline Because of its historic background & & & 0.502 \\
\hline Because of the physical nature of the site & & & 0.427 \\
\hline Because you wanted to have a day out & & 0.694 & \\
\hline Because it was on your way to another site & & 0.649 & \\
\hline Because there was no entrance fee & & 0.612 & \\
\hline $\begin{array}{l}\text { Because you wanted to have some } \\
\text { entertainment }\end{array}$ & & 0.566 & \\
\hline Because you wanted to relax & & 0.522 & \\
\hline
\end{tabular}

Extraction Method: Principal Component analysis.

Rotation Method: Oblimin with Kaiser Normalization.

Rotation converged in 10 iterations.

*The highest factor each motivation was loaded on is highlighted

**The total variance explained by factor one is $26.24 \%$, by factor two is $13.57 \%$, by factor three is $8.7 \%$. 
Table 2: Matrix of motivations to visit Massada

\begin{tabular}{|c|c|c|c|}
\hline \multirow{2}{*}{ Tourist motivation* } & \multicolumn{3}{|c|}{ Components** } \\
\hline & $\begin{array}{r}\text { Heritage / } \\
\text { Emotional } \\
\text { Experience } \\
\end{array}$ & $\begin{array}{l}\text { Recreational } \\
\text { Experience }\end{array}$ & $\begin{array}{c}\text { Cultural } \\
\text { /Educationa } \\
\text { Experience }\end{array}$ \\
\hline Initial Eigenvalues & 4.453 & 1.966 & 1.836 \\
\hline Because you felt a sense of belonging to the site & 0.869 & & \\
\hline Because it is part of your own heritage & 0.826 & & \\
\hline Because you wanted to feel emotionally involved & 0.764 & & \\
\hline Because you wanted to pray there & 0.688 & & \\
\hline Because of its religious characteristics & 0.675 & & \\
\hline $\begin{array}{l}\text { Because you thought it was important to visit the } \\
\text { site }\end{array}$ & 0.512 & & 0.499 \\
\hline Because you felt obliged to visit the site & 0.503 & & \\
\hline Because you felt you should visit the site & 0.500 & & 0.436 \\
\hline Because you wanted to learn about the site & & & 0.778 \\
\hline Because of its historic background & & & 0.662 \\
\hline $\begin{array}{l}\text { Because it is a world-famous site that you had to } \\
\text { see once in your life }\end{array}$ & & & 0.662 \\
\hline Because of the physical nature of the site & & & 0.453 \\
\hline Because you wanted to have some entertainment & & 0.733 & \\
\hline Because you wanted to have a day out & & 0.725 & \\
\hline Because it was on your way to another site & & 0.620 & \\
\hline Because you wanted to relax & & 0.576 & \\
\hline
\end{tabular}

Extraction Method: Principal Component analysis.

Rotation Method: Oblimin with Kaiser Normalization.

Rotation converged in 8 iterations.

*The highest factor each motivation was loaded on is highlighted

**The total variance explained by factor one is $27.83 \%$, by factor two is $12.29 \%$, by factor three is $11.48 \%$. 
Table 3: Tourists' perception of the sites in relation to their own heritage.

\begin{tabular}{|c|c|c|c|c|c|c|c|}
\hline Wailing Wall $(\mathrm{n}=304)$ & 0 & 1 & 2 & 3 & 4 & 5 & 6 \\
\hline $\begin{array}{l}\text { To what extent do you consider } \\
\text { the site as part of your own } \\
\text { heritage }\end{array}$ & $26.3 \%$ & $5.9 \%$ & $9.9 \%$ & $10.5 \%$ & $9.9 \%$ & $9.5 \%$ & $28 \%$ \\
\hline $\begin{array}{l}\text { The site represents something } \\
\text { which relates to your identity }\end{array}$ & $32.9 \%$ & $7.6 \%$ & $10.2 \%$ & $10.9 \%$ & $8.6 \%$ & $6.9 \%$ & $23 \%$ \\
\hline $\begin{array}{l}\text { The site represents something } \\
\text { which relates to your present } \\
\text { existence }\end{array}$ & $32.2 \%$ & $6.9 \%$ & $8.9 \%$ & $13.8 \%$ & $8.9 \%$ & $7.9 \%$ & $21.4 \%$ \\
\hline $\begin{array}{l}\text { The site generates a sense of } \\
\text { belonging for you }\end{array}$ & $32.9 \%$ & $9.5 \%$ & $6.9 \%$ & $10.2 \%$ & $10.5 \%$ & $7.2 \%$ & $22.7 \%$ \\
\hline $\begin{array}{l}\text { During the visit you felt that part } \\
\text { of your own heritage was } \\
\text { displayed }\end{array}$ & $34.2 \%$ & $5.9 \%$ & $7.9 \%$ & $11.2 \%$ & $10.5 \%$ & $7.6 \%$ & $22.7 \%$ \\
\hline
\end{tabular}

Massada $(\mathrm{n}=136)$

To what extent do you consider

\begin{tabular}{lllllll}
\hline $30.9 \%$ & $5.1 \%$ & $8.8 \%$ & $14 \%$ & $11 \%$ & $14.7 \%$ & $15.4 \%$
\end{tabular}
the site as part of your own heritage

The site represents something which relates to your identity The site represents something which relates to your present existence

The site generates a sense of belonging for you During the visit you felt that part of your own heritage was displayed

\begin{tabular}{rrrrrrr}
$42.8 \%$ & $8 \%$ & $13 \%$ & $14.5 \%$ & $7.2 \%$ & $2.9 \%$ & $11.6 \%$ \\
$44.2 \%$ & $5.1 \%$ & $12.3 \%$ & $12.3 \%$ & $9.4 \%$ & $4.3 \%$ & $12.3 \%$ \\
& & & & & & \\
$45.9 \%$ & $9.4 \%$ & $10.1 \%$ & $10.1 \%$ & $7.2 \%$ & $6.5 \%$ & $10.9 \%$ \\
$41.3 \%$ & $8.7 \%$ & $9.4 \%$ & $10.1 \%$ & $10.9 \%$ & $8.7 \%$ & $10.9 \%$ \\
\hline
\end{tabular}

$0=$ Not part of their own heritage

$6=$ Part of their own heritage 
Table 4: Pearson correlations between tourists' perceptions and motivations

Heritage Recreation Learning

motivation motivation motivation

$\begin{array}{llll}\text { Tourists' perception of Massada in } & 0.571^{* *} & 0.149^{*} & 0.758^{* *}\end{array}$ relation to their own heritage

Tourists' perception of the Wailing

$0.804 * * \quad-0.046$

$0.132 *$

Wall in relation to their own heritage

*Correlation is significant at the 0.05 level (1-tailed)

**Correlation is significant at the 0.001 level (1-tailed) 
Table 5: Means ( and standard deviations) of the motivations according to perceptions

Motivation

Perception of the site

Heritage /

Recreational

Cultural

Emotional

Experience

/Educational

Experience

Experience

Wailing Wall $(\mathrm{n}=304)$

Absolutely part of the tourists' own

heritage $(n=88)$

$4.651^{\mathrm{a}}$

(0.779)

$3.872^{\mathrm{a}}$

(1.141)

0.588

$3.217^{\mathrm{b}}$

$3.904^{\mathrm{a}}$

(1.112)

0.819

(1.090)

$3.425^{\mathrm{b}}$

(1.020)

heritage $(n=136)$

$1.920^{\mathrm{c}}$

(1.104)

0.745

(0.726)

(0.840)

$(\mathrm{n}=80)$

$F(2,304)=185.33$
$P<0.001$

$\mathrm{F}(2,304)=$

$\mathrm{F}(2,304)=1.684$

$\mathrm{P}<0.01$

NS

\begin{tabular}{|c|c|c|c|}
\hline Massada $(n=136)$ & & & \\
\hline $\begin{array}{l}\text { Absolutely part of the tourist' own } \\
\text { heritage }(n=17)\end{array}$ & $\begin{array}{l}4.404^{\mathrm{a}} \\
(1.022)\end{array}$ & $\begin{array}{l}4.794^{\mathrm{a}} \\
(0.767)\end{array}$ & $\begin{array}{l}1.794 \\
(1.591)\end{array}$ \\
\hline $\begin{array}{l}\text { Part of the tourists own heritage } \\
(n=49)\end{array}$ & $\begin{array}{l}3.002^{b} \\
(1.283)\end{array}$ & $\begin{array}{l}4.435^{b} \\
(1.184)\end{array}$ & $\begin{array}{l}1.520 \\
(1.402)\end{array}$ \\
\hline \multirow[t]{2}{*}{$\begin{array}{l}\text { Not part of the tourists' own heritage } \\
(\mathrm{n}=70)\end{array}$} & $\begin{array}{l}1.483^{c} \\
(0.946)\end{array}$ & $\begin{array}{l}3.895^{\mathrm{b}} \\
(1.248)\end{array}$ & $\begin{array}{l}1.196 \\
(1.215)\end{array}$ \\
\hline & $\begin{array}{r}\mathrm{F}(2,135)=61.128 \\
\mathrm{P}<0.001\end{array}$ & $\begin{array}{r}\mathrm{F}(2,135)=5.492 \\
\mathrm{P}<0.01\end{array}$ & $\begin{array}{r}\mathrm{F}(2,135)=1.749 \\
\mathrm{NS}\end{array}$ \\
\hline
\end{tabular}

Note: within each column, cells with different letters are significantly $(\mathrm{p}<0.05)$ different from one another. 